\title{
California against cronyism
}

The scale of funds set to be spent by the state on stem-cell research necessitates strong governance.

7 he California Institute for Regenerative Medicine (CIRM) has been making up for lost time. It didn't award a single grant until more than a year after California taxpayers voted it into existence, because lawsuits were holding up its funding. Now the agency is about to award another round of grants, which will bring its total spending to just over $\$ 520$ million. The upcoming awards will fund a network of new and renovated buildings across the state - a striking achievement, all the more remarkable for coming in the same year that Governor Arnold Schwarzenegger asked the state's public universities to cut the rest of their budgets across the board.

So much for the CIRM's good news. Now for the growing pains. Several episodes over the past year have highlighted an inherent problem with the CIRM's structure: the board that distributes its funding is stacked with representatives from the universities that benefit most from those disbursements. The CIRM has enacted rules to try to limit the conflicts of interest posed by this arrangement. They don't go far enough. At one meeting in January, for instance, CIRM board members from institutions that had applied for a facilities grant voted to deny one of these grants to an institution that has no representatives on the CIRM board (see page 18).

Another potential conflict is sure to become a bigger issue if, as the CIRM has promised, its discoveries yield commercializable results. Some in the California state legislature, such as Senator Sheila Kuehl (Democrat), want to ensure that treatments resulting from the CIRM can be afforded by all taxpayers footing the bill. But the CIRM must also court biotechnology companies if its discoveries are to make it to the clinic, and these companies want maximum control over their pricing options.

The CIRM requires companies to which it gives money to offer any resulting drugs "at a price as provided in the California Discount Prescription Drug Program" to people eligible for that programme. The CIRM also requires academic institutions to license their CIRMfunded inventions "only to persons that agree to have a plan in place at the time of commercialization to provide access to resultant therapies and diagnostics for uninsured California patients".

But these relatively vague requirements lack teeth, a fact that Senators Kuehl and George Runner (Republican) are attempting to address with legislation requiring CIRM grantees and licencees to "sell drugs at a price that does not exceed any benchmark price in the California Discount Prescrip-
"The CIRM must be coaxed into serving its most important constituency - the taxpayers of California." tion Drug Program", a measure aimed at ensuring affordability, and a sensible one at that. This proposal is a way to nudge the CIRM towards something it has already promised - guaranteed access for taxpayers to the results of the work they have funded. It also attempts to strengthen the voice of the public in setting the CIRM's path - a voice that, although institutionalized on the CIRM's board, has competed there with mixed success against academic and industrial interests.

This will be the CIRM's main procedural challenge. For the agency to succeed, patient advocates and other public representatives must fight the tendency of the academic institutions on the board to hoard dollars. As the patient advocates grow into their roles as full partners, and with help from well-intentioned lawmakers such as Kuehl, the CIRM must be coaxed into serving its most important constituency - the taxpayers of California. The roles themselves are not unusual in the world of governance, but here the stakes are exceptionally high.

\section{A research menu}

\section{More spending on agricultural science is needed to help resolve the world's food crisis.}

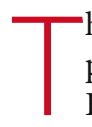

his was not a sudden crisis. It may be only this spring that food prices have started sparking riots on the streets of Haiti and Egypt, not to mention rice rationing at Wal-Mart's cash-andcarry stores, but food prices have been rising since 2000 . The rises accelerated in 2006, when global cereal stocks dropped to levels not seen since the early 1980s. And although the factors driving them are many and various, a good few of them look likely to persist for years to come.

Nor is the crisis unremittingly heinous. Higher food prices, other things being equal, mean higher farm incomes, and there are a lot of poor farmers in the world who could do with such a boost. But although this may suggest benefits for some in the future, the net effect so far has been negative. An interim report released by the World Bank in April says that seven years' poverty reduction has been undone by the past two years of high staple-food prices.

The causes of these shortages are not easily undone, and some of them are things no one should want to undo. In China and India there is ever more - and utterly reasonable - demand for a third meal in the day and more meat in the diet. In Australia prolonged drought has had a severe effect on wheat production. High energy prices mean costly fertilizers and insecticides, not to mention making farm machinery more expensive to run. In the United States, more and more corn (maize) goes to making ethanol, raising the price of both corn and other cereals that can substitute for it.

There are various ways in which the fruits of scientific research might have helped ease the suffering that comes from this confluence of factors. But here, too, the harvest is not what it might have been. Public spending on basic agricultural research fell during the 1980s and 1990s in rich countries (see page 8). The proportion of US aid ploughed into agriculture wilted from $25 \%$ to $1 \%$, bilateral farming aid from Europe 